\author{
S. V. Ivanov ${ }^{1}$, Corr. Member of the NAS of Ukraine, \\ Dr. Sc. (Econ.), Prof., \\ orcid.org/0000-0002-1205-3797, \\ O. B. Vatchenko ${ }^{2}$, Cand. Sc. (Econ.), Assoc. Prof., \\ orcid.org/0000-0003-4937-2641, \\ K. O. Svystun ${ }^{2}$, \\ orcid.org/0000-0003-3817-050X, \\ B. S. Vatchenko ${ }^{2}$, Cand. Sc. (Econ.), Assoc. Prof., \\ orcid.org/0000-0002-6238-3719, \\ O. V. Oskoma ${ }^{1}$, Cand. Sc. (Econ.), \\ orcid.org/0000-0002-1429-2070
}

1 - Pridneprovsk State Academy of Civil Engineering and Architecture, Dnipro, Ukraine, e-mail: ivanovsv@abkdnipro.com 2 - University of Customs and Finance, Dnipro, Ukraine, e-mail: alex1255211@gmail.com

\title{
ANALYSIS OF DECOUPLING OF ECONOMIC GROWTH, ENVIRONMENTAL PRESSURE AND RESOURCE USE IN DNIPROPETROVSK REGION
}

Purpose. To define the relationship between economic growth, various types of environmental pollution and the use of natural resources in Dnipropetrovsk region, to justify measures to reduce the adverse impacts of industry on the environment.

Methodology. The methodology of research on the relationship of economic growth, environmental pollution and the use of natural resources in the region is based on the methods of scientific knowledge, specifically observation, comparison, analysis, dialectical method, statistical analysis are used.

Findings. The effect of relative decoupling by types of environmental pollution and resource use at the regional level in the general dynamics for 2013-2017 was not found. It is coincides with the national trend and indicates the existence of problems for the region and the state in achieving sustainable development. Absolute decoupling was found at the regional level for all types of environmental pollution in 2017 compared to 2013-2014, fuel use for production and household needs, natural gas and motor gasoline in 2013-2017. There are more cases of absolute decoupling at the level of Dnipropetrovsk region than at the state level. According to the method by P. Tapio, between the economic growth of the region and the majority of types of pollution in 2013-2017 there was predominantly recessive coupling. Between the growth rates of the gross regional product of Dnipropetrovsk region and carbon dioxide emissions in 2016 was an expansive negative decoupling. Between economic growth and resource consumption in the region there was found systemic overcoupling on fresh water in 2014 and 2016, volumes of harvesting liquid wood in 2015-2016, firewood for heating in 2013-2016, and fuel briquettes and wood pellets and other natural raw materials in 2015 and 2017.

Originality. Decoupling factors were studied at the system level, which estimate a degree of relation between environmental pollution, resource use and economic growth. With the lack of economic growth, there is found a phenomenon of negative decoupling - overcoupling, which indicates high rates of resource use.

Practical value. The results of the decoupling analysis are recommended to be used in the formation and adjustment of strategic programs for the sustainable development of Dnipropetrovsk region.

Keywords: region, sustainable development, resource use, ecological pressure, decoupling, overcoupling

Introduction. Regional development in Ukraine is marked by significant differences in the structure of regional economies. Heavy industry enterprises are located mainly in the eastern economic regions of the state (Northeast, Dnipro, Donetsk), and cause significant environmental pressure affecting biodiversity and ecosystems. The concept of "green" economy is the opposite of the existing "brown" economy in Ukraine and is based on the idea of a "triple" gain from achieving the goals of economic well-being, social justice, and environmental protection and conservation. Thus, the introduction of a green economy is the most promising way of achieving sustainable development in Ukraine. The destruction of the existing connection between economic growth, environmental pressures, and resource consumption, in favor of reducing the rate of environmental pollution and waste-free use of natural resources in the context of sustainable economic growth, is known as decapitation. Undoubtedly, the effect of decoupling is considered to be an important component of the movement towards a "green" economy, while the acceleration of the decoupling process is a fundamental factor in future well-being of humanity [1].

Literature review. The issue of interconnection between economic growth, environmental pressure and resource use is a matter of the International Resource Panel, which has published, in particular, the following reports:

(c) Ivanov S.V., Vatchenko O. B., Svystun K. O., Vatchenko B. S., Oskoma O. V., 2019
- 2011 - "Decoupling Natural Resource Use and Environmental Impacts from Economic Growth", where, the authors have proved a close correlation between the resource consumption and economic prosperity, and refuted the phenomenon of resource decoupling in a global scale, by analyzing the dynamics of natural resource consumption on global level [1];

- in 2014, "Decoupling 2: technologies, opportunities and policy options" [2], where the authors highlighted the existing technological perspectives and opportunities for both developing and developed countries to accelerate the effect of decoupling and obtain environmental and economic benefits of increasing the productivity of resource use;

- in 2016, "Global material flows and resource productivity", the authors noted that "global resource productivity has declined since 2000 and the global economy now needs more resources per unit of GDP than at the beginning of the century"; the situation where the growth of material flows is faster than the growth of gross domestic product, is proposed to be called "overcoupling", which is the opposite phenomenon to the decoupling [3];

- in 2019 - "Global resources outlook. 2019: natural resources for the future we want", the authors analyzed the demographic and socio-economic drivers of natural resource extraction and use on the global level, and described how these drivers and environmental pressure associated with them caused current condition of the environment; in particular, it is estimated that from 1970 to 2017, the global annual output of 
material resources increased from 27 billion tonnes to 92 billion tonnes and continues to grow [4].

Anders Wijkman and Kristian Skånberg in the report for the Roman Club "The Circular Economy and Benefits for Society Jobs and Climate Clear Winners in an Economy Based on Renewable Energy and Resource Efficiency" [5] noted there is a need to use all kinds of natural resources in a much more efficient way than hitherto. Thus there is an urgent need of decoupling - a transition to an inclusive and circular economy. "Decoupling" itself is defined by the authors as "the ability of an economy to grow without corresponding increases in energy and resource use (source limits) and in environmental pressure (sink limits)".

Asian scientists X. Y. Zeng and W. M. Wong, in their article [6], investigated the extent of decoupling of economic growth and types of environmental pollution in Kaohsiung, Taiwan, using the method and terminology of Finnish scientist P. Tapio. We consider his scientific approach is relevant to use in this research.

Some Russian scientists have investigated decoupling in certain entities of the Russian Federation. For example, V.P. Samarina and G. T. Shkiperova found the effect of decoupling between gross regional product and emissions into the atmosphere from stationary sources of pollution in Murmansk region [7] and the Republic of Karelia [8]. S. N. Kirillov, A. A. Pakin, N. I. Tul'ska investigated the relationship between gross regional product and emissions from stationary sources of pollution in Tatarstan (including analysis of districts and cities) and in some areas of Volga region [9]. Taking into account the large scale of the research of these scientists, the obtained results are variable.

A complex study on the Ukrainian regions' economic growth decoupling, factors influencing environment and resource consumption was carried out by I. M. Sotnik and L.A. Kulik [10]. They concluded that there was no effect of decoupling by environmental pressure and resource factors in the regions of Ukraine in 2008-2012. Other scientist A. Gorskyi [11] researched the decoupling of economic growth and environmental pressure in Ukraine and regions in 2001-2012. $\mathrm{He}$ found the absence of the decoupling effect during this period. However, examining the decoupling indices, A. Gorskyi found the phenomenon of decoupling in some regions, in particular in Dnipropetrovsk (2001-2006), Luhansk (20042009), Mykolaiv (2001-2005), Vinnytsia (2007-2011) and Ivano-Frankivsk (2001-2004 and 2006-2011) regions.

Barzhina A.V. in the article [12] investigated decoupling of economic growth and pollutant emissions into atmosphere from stationary sources of pollution in Ukraine and its regions, except for the cities of Kyiv and Sevastopol and the Autonomous Republic of Crimea, for 2009-2014. The author discovered the absence of the decoupling effect both in Ukraine and in its regions.

The analysis of the dependence of emissions of pollutants and carbon dioxide in Dnipropetrovsk region on the production output in the region was carried out by G. Yu. Yeliseyeva [13], she proved that there is a coincidence of decoupling dynamics in this region with the national decoupling dynamics by these types of pollution in 2007-2012.

Litvak S. M. and Litvak O.A. [14], analyzed the interconnection between the economic growth, resource use and the formation of hazardous wastes of I-III classes of danger in the economy of Mykolaiv region. Scientists found out that the decoupling effect in this region in 2010-2015 was only by the consumption of energy materials and oil products.

Unsolved aspects of the problem. There is not enough attention paid to the period 2013-2017 in the economy of Dnipropetrovsk region in the works by foreign and native authors, devoted to the study of decoupling of economic growth, environmental pressure and resource use in the regions.

Purpose. The goal of the article is to study the interconnection between economic growth, different types of environ- mental pollution and the natural resource use in Dnipropetrovsk region and to substantiate measures for the reduction of negative industry effect on the environment of Ukraine.

The description of the research methodology (structures, order). The calculation of environmental pressure decoupling factor and resource decoupling is given in formulas $(1-3)$ [11]

$$
\begin{aligned}
& \text { Decoupling Index }=\frac{E P_{E}}{D F_{E}} / \frac{E P_{B}}{D F_{B}}=\frac{E P_{E}}{E P_{B}} / \frac{D F_{E}}{D F_{B}}=\frac{I_{E P}}{I_{D F}} ; \\
& \text { Decoupling Index }=\frac{N_{E}}{D F_{E}} / \frac{N_{B}}{D F_{B}}=\frac{N_{E}}{N_{B}} / \frac{D F_{E}}{D F_{B}}=\frac{I_{N}}{I_{D F}} ;
\end{aligned}
$$

Decoupling Factor $=1-$ Decoupling Index,

where $D F_{E}, D F_{B}$ (Driving Force) is the indicator of economic growth, at the state level - gross domestic product (GDP), at the regional level - gross regional product (GRP), in the end year and basic year; $N_{E}, N_{B}$ are the amount of used natural resources (mineral, forest, water, and other natural resources) in the end year and basic year, natural units; $E P_{E}, E P_{B}$ (Environment Pressure) are indicators of environmental pressure, natural units; $I E_{P}$ is the growth rate, or index of the relative change of environmental pressure in the end period compared to the basic period, $\%$; $I_{N}$ is the growth rate of natural resource use, \%; $I D_{F}-$ quantum index of Gross Domestic Product (at the state level) or quantum index of Gross Regional Product (at the regional level), \%.

The Decoupling Index reflects the elasticity or percent change in environmental pressure (resource use) in case of change in the quantum index of the Gross Domestic Product or the quantum index of the Gross Regional Product at $1 \%$ per certain period, in this study - per year.

Two main indicators of atmospheric pollution are taken into account to calculate decoupling indices by environmental pressure factors, namely, the amount of pollutant emissions and the amount of carbon dioxide emissions into the atmosphere from stationary sources of pollution; the indicator of hydrosphere pollution - unregulated wastewater discharge into surface water bodies; and two main indicators of lithosphere - the amount of waste generation of IIII class of hazard and amount of waste generation of IV class of hazard. Thus, five types of environmental pressure were selected.

Indicators of use of freshwater, fuel for production, operational and domestic needs (taking into account the sales to the population and gas stations retails), volume of felling of merchantable wood and indicators of fuel use - coal, natural gas, motor gasoline, gas oil (diesel fuel), wood for heating, fuel briquettes and pellets from wood and other natural raw materials are selected to calculate resource decoupling.

Integral indices of decoupling by factors of environmental pressure $\left(F_{I}\right)$ and resource use $(E I)$ are calculated using the geometric mean of the growth rate of all types of pollution or resources use in a given year using formulas $(4,5)[11]$

$$
\begin{aligned}
F_{I}=1 & -\left(\sqrt[m]{\frac{E P_{E 1}}{E P_{B 1}} \times \frac{E P_{E 2}}{E P_{B 2}} \times \ldots \times \frac{E P_{E m}}{E P_{B m}}} / \frac{D F_{E}}{D F_{B}}\right)= \\
& =1-\left(\sqrt[m]{I_{E P_{1}} \times I_{E P_{2}} \times \ldots \times I_{E P_{m}}} / I_{D F}\right) \\
E_{I}= & 1-\left(\sqrt[n]{\frac{N_{E 1}}{N_{B 1}} \times \frac{N_{E 2}}{N_{B 2}} \times \ldots \times \frac{N_{E n}}{N_{B n}}} / \frac{D F_{E}}{D F_{B}}\right)= \\
& =1-\left(\sqrt[n]{I_{N_{1}} \times I_{N_{2}} \times \ldots \times I_{N_{n}}} / I_{D F}\right),
\end{aligned}
$$

where $m$ is the number of environmental pressure factors, or the number of types of pollution; $n$ is the number of used natural resources; $1,2, \ldots, m$ are specific types of environmental pressure $; 1,2, \ldots, n$ are specific types of used natural resources.

Calculated factors of decoupling can be explained in the following way [11]: 
1. Decoupling Factor $>0$, and increases in dynamics there is a decoupling effect, that is to say, there is a decrease in environmental pressure or saving of natural resources and economic subsystem pace of development increase.

2. Decoupling Factor $<0$, and decreases in dynamics economic development causes an essential increase of environmental pressure or depletion of natural resources.

3. Decoupling Factor $=0$, testifies the equal rate of economic growth and environmental pressure or the use of natural resources, and is possible under the following conditions: a) GDP or GRP growth rate and environmental pressure (or resource use) both are $100 \%$ - in this situation, the rate of natural resource depletion will not change at a sustainable level of environmental capacity; b) GDP or GRP growth rate and environmental pressure (or resource use) are more than $100 \%$ - the rate of natural resource depletion increases at a sustainable level of environmental capacity.

In the analysis of decoupling indices, a method and terminology by Finnish scientist P. Tapio was used. He proposed three main categories of decoupling, which are divided into 8 situations (Table 1).

According to Table 1, the decoupling of economic growth and environmental pressure can be divided into three types: weak - in economic growth $(\triangle D F)$, accompanied by an increase in environmental pressure $(\triangle E P)$; strong - in the conditions of economic growth and reduction of environmental pressure; recessive - in the conditions of simultaneous reduction of economy and environmental pressure. Coupling of economic growth and environmental pressures can be expansive in the conditions of simultaneous growth of the economy and environmental pressure, and recessive - in the condition of their reduction. Negative decoupling of economic growth can be expansive-negative if economic growth and environmental pressures grow simultaneously; strongly negative - in the condition of the economic reduction, accompanied by the environmental pressure increase; and weakly-negative, while both economic and environmental pressure is reducing. In each situation, the values of the decoupling index $(D I)$ are the main criteria for assigning a particular case to a certain category and the decoupling situation.

The study of overcoupling, or excess of the resources use rate over the growth rate of the gross regional product of Dnipropetrovsk region, requires the creation of a special methodology, because the concept itself is new and was proposed in the report "Global material flows and resource productivity" by the International Resource Panel in 2016. In the article, overcoupling is recorded when indices of natural resource use in the region's economy, calculated on the basis of official statistics absolute data, in percentage to the previous year, exceed the index of GRP physical volume of Dnipropetrovsk region in prices of previous year.

Table 1

Decoupling category and decoupling situation [6]

\begin{tabular}{|l|l|c|c|c|}
\hline $\begin{array}{c}\text { Decoupling } \\
\text { category }\end{array}$ & Decoupling situation & $\Delta E P$ & $\Delta D F$ & $D I$ \\
\hline \multirow{2}{*}{ Decoupling } & Weak decoupling & $\Delta E P>0$ & $\Delta D F>0$ & $0-0.8$ \\
\cline { 2 - 5 } & Strong decoupling & $\Delta E P<0$ & $\Delta D F>0$ & $<0$ \\
\cline { 2 - 5 } & Recessive decoupling & $\Delta E P<0$ & $\Delta D F<0$ & $>1.2$ \\
\hline Coupling & Expansive coupling & $\Delta E P>0$ & $\Delta D F>0$ & $0.8-1.2$ \\
\cline { 2 - 5 } & Recessive coupling & $\Delta E P<0$ & $\Delta D F<0$ & $0.8-1.2$ \\
\hline \multirow{2}{*}{$\begin{array}{l}\text { Negative } \\
\text { decoupling }\end{array}$} & $\begin{array}{l}\text { Expansive negative } \\
\text { decoupling }\end{array}$ & $\Delta E P>0$ & $\Delta D F>0$ & $>1.2$ \\
\cline { 2 - 5 } & $\begin{array}{l}\text { Strongly negative } \\
\text { decoupling }\end{array}$ & $\Delta E P<0$ & $\Delta D F<0$ & $<0$ \\
\cline { 2 - 5 } & $\begin{array}{l}\text { Weakly negative } \\
\text { decoupling }\end{array}$ & $\Delta E P<0$ & $\Delta D F<0$ & $0-0.8$ \\
\hline
\end{tabular}

Results. To find occurrences of absolute decoupling by the factor of environmental pressure and resources use in Dnipropetrovsk region in 2013-2017, the absolute values of these factors from official statistical sources were analyzed, in particular: complex statistical publications of the State statistics service of Ukraine - statistical yearbooks of Ukraine 2013-2017 [15], Statistical collected book "Regions of Ukraine" for 2015 [16] and 2018 [17], and data from official sites of State statistics service of Ukraine [18] and The main department of statistics in Dnipropetrovsk region [19]. The following results were obtained:

- unregulated wastewater discharge into surface water bodies in the region was cut down from 325 million $\mathrm{m}^{3}$ in 2013 to

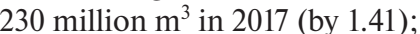

- general use of fuel for production, operational and domestic needs in the region was cut down from 26.4 million $t$ of equivalent fuel in 2013 to 19.2 million $t$ of equivalent fuel in 2017 , almost by 1.38 ;

- use of natural gas in the region was cut down from 4972.4 million $\mathrm{m}^{3}$ in 2013 to 3281.7 million $\mathrm{m}^{3}$ in 2017, almost by one and a half;

- use of motor gasoline in the region was cut down from 336.6 thousand tn. in 2013 to 170.0 thousand tn. in 2017, almost twice.

Reduction of absolute indicators of four other factors of environmental pressure, of total use of fuel, of consumption of natural gas and coal in 2017 compared to 2013-2014 shows the achievement of an absolute decoupling phenomenon in the economy of the region by all types of environmental pollution and some types of fuel resources. Among the reasons for this phenomenon are: decrease in economic activity of industrial enterprises of the region in 2013-2017; resource-efficient measures implementation and greening of production processes at enterprises; fuel consumption reduction, including natural gas and coal, through the development of alternative energy in the region: construction of solar energy facilities and solid fuel boilers. The dynamics of absolute decoupling in the region not always coincide with the dynamics of this phenomenon on the national level. In 2017, in Ukraine, compared to 2014, the absolute values of the following types of environmental pollution decreased: the amount of pollutant emissions and the amount of carbon dioxide emissions into the atmosphere from stationary sources of pollution by 1.30 and 1.34 times correspondingly; the generation of waste of I-III class of dangerous in 1.22 times.

Absolute decoupling in the country was achieved by the use of freshwater - it was cut down in 2017 compared to 2014 by 1.27 times; total fuel use was decreased by 1.20 times; coal by 1.26 times; natural gas - by 1.23 times; petrol - by 1.56 times; gas oil - by 1.06 times $[15,18]$. The year 2014 is taken as a basis of comparison due to the need to study the absolute decoupling of natural resources use at the same territorial area of Ukraine, i.e. not taking into account the temporarily occupied territory of the Autonomous Republic of Crimea and temporarily occupied parts of the territories of Donetsk and Luhansk regions.

To identify occurrences of relative decoupling between economic growth and different types of environmental pressure in Dnipropetrovsk region in the dynamics in 2013-2017, it is necessary to analyze the calculated decoupling factors (Table 2).

The economy of Dnipropetrovsk region was in recession a year longer than the economy of Ukraine, namely in 20132016, when there was a negative growth of the region's economy, and the physical volume indices of the gross regional product did not reach $100 \%$ [20]. Despite this fact, environmental pressure in the region in 2013-2017 was unstable and sometimes had a negative value, for instance in 2016 for pollutants and carbon dioxide emissions, or in 2017 for wastes generation of IV class of hazard. So, there was no effect of decoupling between economic development and environmental 
Decoupling factors by environmental pressure in the economy of Dnipropetrovsk region in 2013-2017 [15-20]

\begin{tabular}{|l|c|c|c|c|c|}
\hline \multicolumn{1}{|c|}{ Decoupling factors } & 2013 & 2014 & 2015 & 2016 & 2017 \\
\hline Decoupling-factor by the emission of pollutants & 0.015 & 0.043 & 0.063 & -0.169 & 0.227 \\
\hline Decoupling-factor by the emissions of carbon dioxide & 0.051 & -0.062 & 0.137 & -0.228 & 0.176 \\
\hline Decoupling-factor by the unregulated wastewater discharge into surface water bodies & 0.145 & -0.009 & 0.052 & 0.071 & 0.077 \\
\hline Decoupling-factor by the generation of hazardous waste of I-III class & -0.115 & 0.197 & -0.017 & 0.031 & -0.008 \\
\hline Decoupling-factor by the generation of hazardous waste of IV class & -0.040 & 0.093 & 0.030 & 0.079 & -0.157 \\
\hline Integral decoupling factor by the environmental pressure from five types of pollution & 0.015 & 0.057 & 0.055 & -0.036 & 0.073 \\
\hline
\end{tabular}

pressures during the study period. The integrated decoupling factor by the environmental pressures from five types of pollution in the region was also unstable, and in 2016 had a negative value.

To identify specific decoupling situations between economic growth and different types of environmental pollution in Dnipropetrovsk region using P. Tapio method (Table 1), let us examine their growth rates and decoupling indices. Pollutant emissions from stationary sources of pollution into the atmosphere in the region declined in 2013-2015 and in 2017. The authors recorded a recessive relationship between pollutant emissions and economic growth in the region in 2013-2015, decoupling indices ranged from 0.937 to 0.985 , and weak decoupling in 2017 based on a decoupling index value of 0.773 . In 2016, the index of physical volume of GRP of Dnipropetrovsk region was $98.4 \%$, and emissions of pollutants increased by a rate of $115.1 \%$ compared to the previous year. But a decoupling situation did not occur since the decoupling index between indicators was 1.169 - less than 1.2, which could allow referring the situation to expansive-negative decoupling.

Carbon dioxide emissions in the region in 2013 and 2015 declined and their growth rates were lower than the growth rates of the region's GRP physical volume in those years. Decoupling indices between the indicators were 0.949 and 0.862 respectively, which shows a recessive link between the indicators. In 2014, carbon dioxide emissions increased at a rate of $101 \%$ while GRP physical volume index in the region reduced by $95.1 \%$. There was no decoupling situation based on the decoupling index value of 1.062 . In 2016, the growth rate of carbon dioxide emissions $(120.9 \%)$ significantly exceeded the growth rate of the regional economy. The decoupling index for this type of pollution in 2016 was 1.228 - the authors recorded expansive-negative decoupling. In 2017, carbon dioxide emissions in the region decreased $(84.1 \%)$ with the simultaneous increase in the region's GRP $(102.1 \%)$; the decoupling index was 0.824 - there was no weak decoupling.

In 2013-2016, a recessive link between GRP growth and unregulated wastewater discharge into surface water bodies was found in the region's economy, decoupling indices from 0.855 to 1.009 . In 2017, the positive growth of the region's economy was accompanied by a decrease in unregulated wastewater discharge $(94.3 \%)$. Decoupling index value -0.923 does not allow classifying this situation as weak decoupling.

In 2013, the rate of waste generation of I-III class of hazard in the region (110.7\%) exceeded the GRP physical volume index of Dnipropetrovsk region $(99.3 \%)$. This occurrence cannot be referred to expansive-negative decoupling because the decoupling index value between the indicators was 1.115 . In 2014-2016, both indicators were declining and decoupling indices ranged from 0.803 to 1.017 - there was a recessive link between the indicators. In 2017, the rate of waste generation of I-III class of hazard $(102.9 \%)$ was almost equal to the index of physical volume of GRP in the region. The decoupling index of 1.008 evidenced the expansive coupling between the growth of the region's economy and the waste generation of these hazard classes.
The rate of waste generation of IV class of hazard in the region in 2013 and 2017 (103.2 and $118.1 \%$, respectively) exceeded the GRP physical volume index. Decoupling indices were respectively 1.040 and 1.157 , so there were no phenomena of expansive-negative decoupling. In 2014-2016, the rate of waste generation of IV class of hazard and the index of physical volume of GRP in the region declined synchronously, and decoupling indices ranged from 0.907 to 0.970 - there was a recessive link between economic growth and waste generation of IV class of hazard.

An integral factor of the environmental pressure from five types of pollution in Dnipropetrovsk region in 2013-2015 was lower than the rate of GRP growth in the region in given years while decoupling indices varied from 0.945 to 0.985 . There was a recessive link between economic growth and the aggregate environmental pressures in the region. In 2016, the integral factor of environmental pressure $(101.9 \%)$ exceeded the extremely low economic growth rate in the region. In 2017, the region's GRP physical volume index exceeded extremely low rate of environmental pressure $(94.3 \%)$ in the region. Decoupling indices in 2016-2017 were 1.036 and 0.927 respectively, which makes it impossible to attribute both occurrences to any decoupling situation.

To identify occurrences of resource decoupling in the economy of Dnipropetrovsk, it is necessary to analyze the calculated decoupling factors by resource use in 2013-2017 in the region (Table 3 ).

The decoupling factors by use of all types of resources in the Dnipropetrovsk region in 2013-2017 were very unstable; this indicates that there is no effect of relative decoupling by the resource factors in the overall dynamics. The tendency for negative values of decoupling factors was most frequent in 2014 and 2016 by the use of freshwater, fuel, coal, gas oil, wood for heating.

The decoupling factors by use of wood for heating were exceptionally negative in 2013-2016, these were years of the region's economy negative growth. Decoupling factors by use of fuel briquettes and pellets from wood and other natural raw materials in 2015 and 2017 were negative, indicating a tendency of wood resources overuse, due to a significant increase in natural gas price and, as a consequence, reduction of its use in favor of cheaper fuel resources. Integral decoupling factors were negative: by use of three types of resources in 2013 and 2015, and by use of six types of fuel resources (in 2013-2014 by five) - in 2013, 2016 and 2017; by use of eight types of resources (in 2013-2014 - seven) excluding the fuel for production, operational and domestic needs - in 2013 and 2016. Therefore, despite the lack of economic growth in 2013-2016, and insignificant economic growth in 2017, in the region, there was a tendency to overuse these resource groups.

To identify occurrences of negative decoupling, or overcoupling, between economic growth and used resources in the region's economy, the authors examine the rate of GRP growth and the use of these resources. The overcoupling by freshwater use in Dnipropetrovsk region was observed in 2014 and 2016 when the rates of this resource use (100.7 and $119.8 \%$ respectively) exceeded the economic growth rate of the region. 
Decoupling-factors by factors of resource use in the economy of Dnipropetrovsk region in 2013-2017 [15-17, 19, 20]

\begin{tabular}{|l|c|c|c|c|c|}
\hline \multicolumn{1}{|c|}{ Decoupling factor } & 2013 & 2014 & 2015 & 2016 & 2017 \\
\hline Decoupling factor by use of fresh water & 0.049 & -0.059 & 0.282 & -0.217 & 0.255 \\
\hline $\begin{array}{l}\text { Decoupling factor by fuel for production, operational and domestic needs (taking into } \\
\text { account the sales to the population and gas stations retails) }\end{array}$ & 0.054 & -0.012 & 0.063 & -0.002 & 0.113 \\
\hline Decoupling factor by volume of felling of merchantable wood & 0.327 & 0.054 & -0.470 & -0.225 & 0.237 \\
\hline Decoupling factor by coal & 0.087 & -0.049 & 0.158 & -0.265 & 0.161 \\
\hline Decoupling factor by nature gas & 0.097 & 0.085 & 0.119 & -0.007 & 0.059 \\
\hline Decoupling factor by motor gasoline & 0.044 & 0.116 & 0.138 & 0.092 & 0.154 \\
\hline Decoupling factor by gas oil (diesel fuel), & 0.018 & -0.005 & 0.036 & -0.028 & -0.025 \\
\hline Decoupling factor by wood for heating & -0.151 & -0.965 & -0.279 & -0.462 & 0.200 \\
\hline Decoupling factor by fuel briquettes and pellets from wood and other natural raw materials & - & - & -1.953 & 0.661 & -1.124 \\
\hline $\begin{array}{l}\text { Integral decoupling factor by use of three types of resources: freshwater, fuel for } \\
\text { production, operational and domestic needs, felling of merchantable wood }\end{array}$ & -0.154 & 0.005 & -0.004 & 0.143 & 0.204 \\
\hline Integral decoupling factor by use of six types of resources (in 2013-2014 - 5 types) & -0.023 & 0.109 & 0.151 & -0.084 & -0.026 \\
\hline $\begin{array}{l}\text { Integral decoupling factor by use of eight type of resources (in 2013-2014 - 7 types) } \\
\text { without fuel for production, operational and domestic needs }\end{array}$ & -0.077 & 0.077 & 0.119 & -0.016 & 0.050 \\
\hline
\end{tabular}

Overcoupling by volume of felling of merchantable wood in the region was recorded in 2015-2016, when the rates of this resource use (132.7 and $120.6 \%$ respectively) significantly exceeded the growth rate of GRP in the region, indicating the extensive depletion of forest resources in Dnipropetrovsk region, namely $9.7 \%$ in 2015 and $1.6 \%$ in 2016.

There was overcoupling in the economy of Dnipropetrovsk region in 2016 by use of coal, the rate of its use was $124.5 \%$ along with a low index of physical volume of the gross regional product. The insignificant increase in the rate of coal consumption $(99.8 \%)$ over the rate of economic development of the region in 2014, or the rate of natural gas use $(99.1 \%)$ over the rate of economic development in 2016 does not allow referring these occurrences to overcoupling.

Overcoupling in the economy of Dnipropetrovsk region was observed by gas oil in 2016, its use rate (101.2\%) exceeded the rate of economic growth in the region; by wood for heating in 2013-2016, the rates of its use varied from 114.3 to $186.8 \%$, in the conditions of negative growth of the economy of the region; by use of fuel briquettes and pellets from wood and other natural raw materials in 2015 and 2017, the rates of which (266.7 and $216.8 \%$ respectively) exceeded the indices of gross regional product physical volume in Dnipropetrovsk region at the same years.

Research on indexes of GRP physical volume in Dnipropetrovsk region and rates of use by three resources types (freshwater, fuel for production, operational and domestic needs, felling of merchantable wood), by six (in 2013-2014 five) types of fuel resources and by eight (in 2013-2014 seven) types of resources, excluding the fuel for production, operational and domestic needs, showed a single case of overcoupling by three types of resources use in 2016, when the growth rate of their total use $(112.5 \%)$ exceeded the GRP growth rate, which had a negative increase $(1.6 \%)$. Overcoupling by six types of fuel resources and by eight types of resources, excluding the fuel for production, operational and domestic needs, in the economy of Dnipropetrovsk region was observed for two years in succession in 2014-2015 when the growth rates of use of these groups of resources were:

- $105.4 \%$ in 2014 by five and $104 \%$ in 2015 by six types of fuel resources;

- $102.4 \%$ in 2014 by seven and $101 \%$ in 2015 by eight types of resources in the condition of negative growth of the region's economy.
Conclusions. As a result of the crisis and recession in the region's economy, which was accompanied by economic contraction, absolute decoupling was achieved between economic growth and all types of environmental pollution, the general use of fuel for production, operational and domestic needs, natural gas and motor gasoline use in 2013-2017. This was caused by the introduction of the clean and energy-saving technologies in the region, the construction of solid fuel boilers and solar power plants, and the reduction of gas consumption by the population due to market situation (setting the market price of gas and its rise in prices).

The analysis of the decoupling factors by the environmental pressure and resource use in the economy of Dnipropetrovsk region did not reveal the effect of relative decoupling in 2013-2017, which indicates that there are problems in the region regarding transition towards sustainable development.

The study on economic development decoupling indices and environmental pressure factors in Dnipropetrovsk region revealed a predominantly recessive relationship between them in 2013-2015. In 2016, there was an expansive-negative decoupling between carbon dioxide emissions and the economy of the region, which had no systemic display in other years.

The systemic display of negative decoupling between economic growth and used resources, or overcoupling, included freshwater use in 2014 and 2016, felling of merchantable wood in 2015-2016, use of wood for heating in 2013-2016, use of briquettes and wood pellets, other natural raw materials in 2015 and 2017 in the region (in 2013-2016 overcoupling in Dnipropetrovsk region was combined with a negative trend economic contraction).

In Dnipropetrovsk region, national trends of extensive use of wood and other natural resources are repeated.

The authors believe that measures to reduce the negative impact of industry on the environment of Ukraine and its regions should include: extensive greening of industry, development of "green" services aimed at reducing the harmful effects of industrial enterprises, and improvement of climate for investing the development of renewable energy in the country. In the long term perspective, the transition of the state economy to the principles of the Third and Fourth Industrial Revolution on the basis of sustainable, inclusive, waste-free and lowcarbon development should partly solve the problem of the negative impact of industry on the environment.

It is relevant to use the decoupling tool in the development of strategic programs for sustainable development of the regions, 
and as a prerequisite and a mean of calculating the success of the implementation of international obligations of the state to achieve the effect of decoupling from the reduction of greenhouse gas emissions and all harmful types of pollution, as well as reducing of natural resources use while steady economic growth.

\section{Regerences.}

1. Fischer-Kowalski, M., Swilling, M., von Weizsäcker, E. U., Ren, Y., Moriguchi, Y., Crane, W., ... \& Sewerin, S. (2011). Decoupling natural resource use and environmental impacts from economic growth. A Report of the Working Group on Decoupling to the International Resource Panel. United Nations Environment Programme. Retrieved from https://www.resourcepanel.org/reports/decoupling-natural-resource-use-andenvironmental-impacts-economic-growth.

2. von Weizsäcker, E. U., de Larderel, J., Hargroves, K., Hudson, C., Smith, M., \& Rodrigues, M. (2014). Decoupling 2: technologies, opportunities and policy options. A Report of the Working Group on Decoupling to the International Resource Panel. Retrieved from https://www.resourcepanel.org/reports/decoupling-2.

3. Schandl, H., Fischer-Kowalski, M., West, J., Giljum, S., Giljum, S., Dittrich, M., ... \& Fishman, T. (2016). Global Material Flows and Resource Productivity. An Assessment Study of the UNEP International Resource Panel. Paris, United Nations Environment Programme. Retrieved from https://www.resourcepanel.org/reports/global-material-flows-and-resourceproductivity-database-link.

4. Oberle, B., Bringezu, S., Hatfeld-Dodds, S., Hellweg, S., Schandl, H., Clement, J., ... \& Zhu, B. (2019). Global Resources Outlook 2019: Natural Resources for the Future We Want. A Report of the International Resource Panel. United Nations Environment Programme. Nairobi, Kenya. Retrieved from https:// www.resourcepanel.org/reports/global-resources-outlook.

5. Wijkmann, A., \& Skanberg, K. (2017). The Circular Economy and Benefits for Society. Jobs and Climate Clear Winners in an Economy Based on Renewable Energy and Resourse Efficien$c y$. Report on research at the request of the Roman Club; translation and publication in Ukrainian with the support of the Ukrainian Association of the Rome Club. Retrieved from http://www.clubofrome.org.ua/wp-content/uploads/2017/08/ The-Circular-Economy-CoR_UA-2.pdf.

6. Zeng, X. Y., \& Wong, W. M. (2014). Decoupling of environmental pressures from economic activities: evidence from Taiwan. Global journal of business research, 8(4), 41-50.

7. Samarina, V. P. (2014). The effect of decoupling in the economic development of the Murmansk region. The North and the market: forming the economic order, 2(39), 24-30.

8. Shpikerova, G. T. (2014). Analysis and modeling of the relationship between economic growth and environmental quality (the case of the Republic of Karelia). Economic analysis: theory and practice, 13(43), 41-49.

9. Kirillov, S. N., Pakina, A.A., \& Tulskaia, N. I. (2017). Assessment of sustainability of development at the regional level: the example of the Republic of Tatarstan. Science Journal of VolSU, Ser. 3: Economics, ecology, 19(4(41)), 127-137. https:// doi.org/10.15688/jvolsu3.2017.4.14.

10. Sotnyk, I. M., \& Kulyk, L. A. (2014). Decoupling analysis of economic growth and environmental impact in the regions of Ukraine. Economic Annals-XXI, 7-8, 60-64.

11. Gorsky, A. (2014). The decoupling effect as a criterion of ecological-oriented economic development of Ukraine. Ekonomika pryrodokorystuvannia i okhorony dovkillia, (8), 23-26. 12. Barzhina, A. V. (2018). Decoupling effect as a tool for analyzing the influence of economic development on environmental conditions in terms of sustainable development. Economy and society, 16, 606-611.

13. Yeliseieva, G. Yu. (2014). Impact assessment of the green economy development using the concept of decoupling. Intellect XXI, 2, 127-135. Retrieved from http://nbuv.gov.ua/ UJRN/int XXI $2014 \quad 216$.
14. Litvak, S. M., \& Litvak, O.A. (2017). Analysis of decoupling indicators by resource factors in context of forming of sustainable development of the region. Collection of scientific works of the National University of Shipbuilding named after Admiral Makarov, 3, 129-135. Retrieved from http://nbuv.gov. ua/UJRN/znpnuk $2017 \quad 3 \quad 18$.

15. State statistics service of Ukraine (2018). Statistical yearbooks of Ukraine since 2013 to 2017. Retrieved from http:// www.ukrstat.gov.ua/druk/publicat/kat_u/publ1_u.htm.

16. Zhuk, I. M. (Ed.) (2015). Statistical collected book"Regions of Ukraine" - 2015. Kyiv: State statistics service of Ukraine, 2015, part. 1. Retrieved from https://ukrstat.org/uk/druk/ publicat/kat_u/2016/zb/12/zb_ru12015pdf.zip.

17. Verner, I. Ye. (Ed.) (2018). Statistical collected book "Regions of Ukraine" - 2018. Kyiv: State statistics service of Ukraine, part 1. Retrieved from http://ukrstat.gov.ua/druk/ publicat/kat u/2018/zb/11/zb ru1ch2018.pdf.

18. Emissions of pollutants and greenhouse gases into the atmosphere from stationary sources of pollution in Ukraine and in regions in 2017. Retrieved from https://ukrstat.org/uk/operativ/ operativ2018/ns/vzrap2017 u.zip.

19. The main department of statistics in Dnipropetrovsk region (official site). Retrieved from http://www.dneprstat.gov.ua. 20. Nikitina, I. M. (Ed.) (2019). Statistical collected book "Gross regional product in 2017'. Kyiv: State statistics service of Ukraine. Retrieved from http://www.ukrstat.gov.ua/druk/ publicat/kat_u/2019/zb/04/zb_vrp_2017.pdf.

\section{Аналіз декаплінгу економічного розвитку, екологічного тиску та споживання ресурсів у Дніпропетровському регіоні}

\section{С. В. Іванов ${ }^{1}$, О. Б. Ватченко ${ }^{2}$, К. О. Свистун ${ }^{2}$, Б. С. Ватченко ${ }^{2}$ О. В. Оскома ${ }^{1}$}

1 - Державний вищий навчальний заклад „Придніпровська державна академія будівництва та архітектури“, м. Дніпро, Україна, e-mail: ivanovsv@abkdnipro.com 2 - Університет митної справи та фінансів, м. Дніпро, Україна, е-mail: alex1255211@gmail.com

Мета. Встановити взаємозв'язок між економічним зростанням, різними видами екологічного забруднення й використанням природних ресурсів у Дніпропетровському регіоні, обгрунтувати заходи зі зниження негативного впливу промисловості на навколишне середовище.

Методика. Методика дослідження взаємозв'язку економічного зростання, екологічного забруднення й використанням природних ресурсів у регіоні грунтується на методах наукового пізнання, а саме: спостереження, порівняння, аналізу, застосовано діалектичний метод, статистичний аналіз.

Результати. Ефекту відносного декаплінгу за видами екологічного забруднення й використання ресурсів на рівні регіону в загальній динаміці за 2013-2017 рр. не виявлено. Це співпадає з національною тенденцією та свідчить про існування проблем для регіону й держави щодо досягнення сталого розвитку. Виявлено абсолютний декаплінг на рівні регіону за всіма видами екологічного забруднення у 2017 р. у порівнянні з 2013-2014 рр., використанням палива на виробничо-експлуатаційні та комунально-побутові потреби, природного газу й моторного бензину у 2013-2017 рр. Випадків абсолютного декаплінгу на рівні Дніпропетровського регіону є більше, ніж на рівні держави. За методом П. Тапіо, між економічним зростанням регіону й більшістю видів забруднення у 2013-2016 рр. був переважно рецесивний каплінг. Експансивно-негативний декаплінг між темпами зростання валового регіонального продукту Дніпропетровщини та 
викидами діоксиду вуглецю в регіоні був у 2016 р. Системний оверкаплінг між економічним зростанням і споживанням ресурсів у регіоні був за свіжою водою у 2014 і 2016 pр., обсягами заготівлі ліквідної деревини у 2015-2016 pр., дровами для опалення у 2013-2016 pp. i паливними брикетами та гранулами з деревини та іншої природної сировини у 2015 і 2017 pp.

Наукова новизна. Системно досліджені показники декаплінгу, що оцінюють ступінь зв'язку між забрудненням навколишнього середовища, використанням ресурсів і зростанням економіки. При відсутності економічного зростання виявлене явище негативного декаплінгу оверкаплінг, що сигналізує про високі темпи використання ресурсів.

Практична значимість. Результати декаплінг-аналізу рекомендовано використовувати при формуванні й коригуванні стратегічних програм сталого розвитку Дніпропетровського регіону.

Ключові слова: регіон, сталий розвиток, використання ресурсів, екологічний тиск, декаплінг, оверкаплінг

\section{Анализ декаплинга экономического развития, экологического воздействия и потребления ресурсов в Днепропетровском регионе}

\section{С. В. Иванов ${ }^{1}$, А. Б. Ватченко ${ }^{2}$, К. А. Свистун ${ }^{2}$,} Б. С. Ватченко ${ }^{2}$, Е. В. Оскома ${ }^{1}$

1 - Государственное высшее учебное заведение „Приднепровская государственная академия строительства и архитектуры“, г. Днепр, Украина, e-mail: ivanovsv@ abkdnipro.com

2 - Университет таможенного дела и финансов, г. Днепр, Украина, e-mail: alex1255211@gmail.com

Цель. Установить взаимосвязь между экономическим ростом, разными видами экологического загрязнения и использованием природных ресурсов в Днепропетровском регионе, обосновать меры по снижению отрицательного воздействия промышленности на окружающую среду.

Методика. Методика исследования взаимосвязи экономического роста, экологического загрязнения и использования природных ресурсов в регионе базируется на методах научного познания, а именно: наблюдения, сравнения, анализа, применен диалектический метод, статистический анализ.

Результаты. Эффекта относительного декаплинга по видам экологического загрязнения и использования ресурсов на уровне региона в общей динамике за 2013-2017 гг. не обнаружено. Это совпадает с национальной тенденцией и свидетельствует о существовании проблем для региона и государства при достижении устойчивого развития. Обнаружен абсолютный декаплинг на уровне региона по всем видам экологического загрязнения в 2017 г. в сравнении с 2013-2014 гг., использованием топлива на производственно-эксплуатационные и коммунально-бытовые потребности, природного газа и моторного бензина в 2013-2017 гг. Случаев абсолютного декаплинга на уровне Днепропетровского региона больше, чем на уровне государства. По методу П. Тапио, между экономическим ростом региона и большинством видов загрязнения в 2013-2017 гг. был преимушественно рецессивный каплинг. Экспансивно-негативный декаплинг между темпами роста валового регионального продукта Днепропетровщины и выбросами диоксида углерода в регионе был в 2016 г. Системный оверкаплинг между экономическим ростом и потреблением ресурсов в регионе был по свежей воде в 2014 и 2016 гг., объемами заготовки ликвидной древесины в 2015-2016 гг., дров для отопления в 2013-2016 гг. и топливными брикетами и гранулами из древесины и другого природного сырья в 2015 и 2017 гг.

Научная новизна. Системно исследованы показатели декаплинга, оценивающие степень связи между загрязнением окружающей среды, использованием ресурсов и ростом экономики. При отсутствии экономического роста обнаружено явление негативного декаплинга - оверкаплинг, что сигнализирует о высоких темпах использования ресурсов.

Практическая значимость. Результаты декаплинг-анализа рекомендовано использовать при формировании и корректировке стратегических программ устойчивого развития Днепропетровского региона.

Ключевые слова: регион, устойчивое развитие, использование ресурсов, экологическое давление, декаплинг, оверкаплинг

Recommended for publication by S.V. Kalambet, Doctor of Economic Sciences. The manuscript was submitted 23.02.19. 